Geology of the Mediterranean basins and margins

The Ocean Basins and Margins. Vol. 4A: The Eastern Mediterranean. Edited by A.E.M. Nairn. W.H. Kanes and F.G. Stehli. Pp.503. (Plenum: New York, 1978.) \$59.40.

ONE might perhaps be forgiven for being surprised that the Mediterranean Sea should be included in a series with the title Ocean Basins and Margins, expecially as some geologists would question whether any or all of the Mediterranean is underlain by true oceanic crust. However, earlier volumes in this series have concentrated on the geology of the land areas marginal to the oceans rather than the geology and geophysics of the basins themselves. A corollary of this seems to be that as the area of the ocean basin being considered decreases, and the proportionate length of the margins increases, so does the length of the treatment given. Thus, whereas the South Atlantic and the North Atlantic each commanded rather less than 600 pages. the Gulf of Mexico and the Caribbean warranted 700 , and the Mediterranean receives over 900 .

In fact, in this latest volume, the imbalance between geology and geophysics, and between the margins and the basins is largely redressed; and more so than previously the editors and publishers have achieved their objective of "presenting surveys of the relevant data, both geological and geophysical, to provide a broad overview of geological processes under and near the Earth's oceans". The main problem, it would seem, was an editorial one: how to marshal such a wealth of excellent material which was obviously too great for a single volume. Thus, despite its title. only half of the review papers in the present volume relate specifically to the Eastern Mediterranean; the four introductory chapters relate to the Mediterranean as a whole: and the last chapter reviews work on the Black Sea and Sea of Azov.

The volume opens with a particularly succinct and lucid overview, by Laubscher and Bernoulli. summarising the palaeogeography and tectonic evolution of the Mediterranean area

- Introduction to Biological Scanning Electron Microscopy by M. A. Hayat (for review, see Nature $\mathbf{2 7 4}$, page $98 ; 6$ July 1978) is published in the UK by MTP Press : Lancaster. since the late Palaeozoic, and making the important distinction between the Palaeozoic 'Palaeotethys', and the Mesozoic 'Tethys', beloved of stratigraphers and sedimentologists. This is followed by a chapter by Hsü, who concentrates on the general tectonic evolution and geophysical characteristrics of the Mediterranean basins, providing a useful, if at times speculative. summary of ideas.

Two lengthy and detailed chapters on geophysical data follow. The first. by Stanley, integrates continuous reflection profiling results and direct sampling to give a picture of postMiocene sedimentation and tectonics. and the second, by lort, reviews all geophysical data, basin by basin, blow by blow.

The remaining six chapters deal with the geology of the land areas marginal to the eastern Mediterranean, and fall conveniently into five regions, each of a comparable size: the area bordering the Adriatic. Greece and the Aegean.

\section{Plasma protein analysis}

Plasma Proteins: Analytical and Preparative Techniques. By P. C. Allen, E. A. Hill and A. M. Stokes. Pp 254. (Blackwell Scientific: Oxford, 1978.) £11.75.

THE authors of this trim publication suggest that it will provide a usefui manual for students embarking upon a project in plasma protein chemistry. However, prospective buyers ought to be advised that over half the text describes general analytical and preparative methods, which are probably already available to them in one or more standard works.

The section on analytical methods concisely describes electrophoretic. immunochemical and molecular weight estimation techniques in theory/ practice format (105 pages). Serum proteins are used as examples to illustrate some of these techniques. Obviously, in practical texts like this. accuracy of description is of prime importance and there seems to be sufficient attention to this point. However, one toxic mistake appears on $\mathrm{pl} 2$ where " $50 \mathrm{~g}$ of mercuric acid" is advocated in a recipe for a protein stain.

The preparative procedures section (41 pages) presents the classical Cohn fractionation of plasma. but the bulk of the text describes gel permeation. ionexchange, affinity chromatography and protein concentration methods. Incidentally. quite a bit of this information is available free: as the authors state
Turkey, the Levant. and Egypt. The geology of Libya. it would seem, has been omitted, and that of Greece, the Aegean, and Cyprus gets rather brief and inadequate treatment.

I was left wondering why it is that the chapters are of such varying lengths. some rather unnecessarily detailed for reviews of this type, and others all too brief. I feel that had each author been kept to a word or page limit. a single and more uniform volume on the whole Mediterranean area could have been produced. Aside from this minor shortcoming. however. the volume is a worthy addition to the series, providing authoritative and comprehensive reviews which will constitute invaluable summaries and sources of references for many years to come.

F. J. Vine

F. J. Vine is Professor of Environmental Sciences at the University of East Anglia. Norwich. UK.

it is "derived ostensibly from the operating instructions issued by various manufacturers",

On p160 the reader can get to grips with practical techniques for isolating specific plasma proteins. About 19 proteins including subclasses (for example, lipoproteins, immunoglobulins. and so on) are covered. Although the authors do not intend this section to be exhaustive, the lack of a description of the preparation of prealbumin is notable. as this is one of the very few plasma proteins of known function. sequence and structure. For the majority of the other proteins. there is a good short review. complete instructions for purification. and sufficient references to enable the original sources to be traced.

collections of practical details for the isolation of proteins are often at the mercy of the original literature, which is notoriously uncritical. However. the authors rightly include more than one point of view where this is appropriate and point out where controversy exists about the homogeneity of a given protein.

There is certainly room for a publication which brings together the widespread literature on isolation of plasma proteins. The material in this book is well presented and very readable, but I feel that by giving such extensive coverage to general biochemical techniques it fails to do justice to the particular plasma proteins described.

M. J. Geisow

M. J. Geisow is a member of the scientific staff at the National Institute for Medical Research, London, UK. 